\title{
Seasonal dynamics of shoot biomass of dominant clonal herb species in an oak-hornbeam forest herb layer
}

\author{
Mateusz Rawlik (i) • Andrzej M. Jagodziński
}

Received: 18 March 2020/ Accepted: 1 August 2020/Published online: 19 August 2020

(C) The Author(s) 2020

\begin{abstract}
Seasonal fluctuations of light availability, nutrient concentrations, and moisture affect plant population traits like density, standing biomass, and flowering. We analyzed seasonal changes of density and shoot biomass of the four most frequent herb species growing in an oak-hornbeam forest community, i.e., Anemone nemorosa, Ficaria verna, Galeobdolon luteum, and Galium odoratum. In 2010 and 2011 plant biomass was harvested from 7 to 10 randomly situated square sample plots $\left(0.36 \mathrm{~m}^{2}\right)$ in the homogenous oak-hornbeam forest community every week in the spring and every two weeks in the summer and autumn. The highest abundance of Anemone nemorosa reached over 1000 shoots per $\mathrm{m}^{2}$, of Ficaria verna 459.5 shoots per $\mathrm{m}^{2}$, of Galium odoratum 83.6 shoots per $\mathrm{m}^{2}$, and of Galeobdolon luteum 98.4 shoots per $\mathrm{m}^{2}$ (means for 2010 and 2011, based on all sample plots). We did not observe negative correlation between density and shoot biomass. Growth rates of vegetative shoot biomass amounted to $0.857 \mathrm{mg} \mathrm{day}^{-1}$ for
\end{abstract}

Communicated by George Yan.

M. Rawlik ( $\square)$

Department of Plant Ecology and Environmental Protection, Adam Mickiewicz University in Poznań, Uniwersytetu Poznańskiego 6, 61-614 Poznań, Poland e-mail: Mateusz.Rawlik@amu.edu.pl

A. M. Jagodziński

Institute of Dendrology, Polish Academy of Sciences,

Parkowa 5, 62-035 Kórnik, Poland
Anemone nemorosa, $0.467 \mathrm{mg} \mathrm{day}^{-1}$ for Ficaria verna, $0.722 \mathrm{mg} \mathrm{day}^{-1}$ for Galium odoratum, and $0.448 \mathrm{mg} \mathrm{day}^{-1}$ for Galeobdolon luteum (means for 2010 and 2011). Spring ephemerals had much higher densities of shoots than summer-greens. Summergreens reached higher biomass of individual shoots than spring ephemerals. Flowering shoots constituted only 4, 2, and $11 \%$ of all shoots for A. nemorosa, $F$. verna, and $G$. odoratum, respectively. More resource availability resulting in high shoot biomass did not translate to higher share of flowering shoots.

Keywords Plant biomass - Plant density - Clonal plants $\cdot$ Oak-hornbeam forest $\cdot$ Seasonal dynamic

\section{Introduction}

Central European oak-hornbeam forest association is a stable, self-organized, and spontaneous ecosystem which occurs in areas without human intervention and disturbances. This forest association is characterized by low ratio of gross primary production to standing crop, a ratio of gross primary production to respiration close to zero, and plants that have long and complex life cycles, usually representing a K-type strategy (Morin 2009). Nevertheless, this static view of the ecosystem obscures processes that contribute to dynamic stability. One example of natural changes 
in deciduous forest associations in the temperate zone is seasonal fluctuations of vegetation cover. During the year many changes may occur, e.g., in light conditions, temperature, moisture, net primary production, or foliage development stage (Abraitienè and Marozas 2011; Eliáš 1984; Jagodziński et al. 2016). The herb layer, the lowest layer of forest association, is dependent, among other factors, on seasonal dynamics of climate and the tree layer in deciduous, and to a lesser extent in mixed forests (Krotoska 1961). Spring ephemerals like Anemone nemorosa and Ficaria verna grow, assimilate, bloom, and bear fruits before full development of leaves and canopy closure, and then all shoots die within a short period (Lapointe 2001). Aboveground shoots of these plant species have short life cycles, but belowground organs store products of assimilation for future development the next spring. Therefore, spring ephemerals can successfully compete with seedlings and annual herbs (Chapin et al. 1990; Suzuki and Stuefer 1999). However, some other plant species growing in oak-hornbeam forest, e.g., Galeobdolon luteum and Galium odoratum, represent a different adaptation strategy to changes in light conditions. Summer-green species such as G. luteum and $G$. odoratum are able to effectively assimilate $\mathrm{CO}_{2}$ at low light intensity, and their daily net primary production rate is lower in comparison with spring ephemerals, but production lasts much longer during the growing season. The highest biomass of summergreen species is observed in late summer or even in early autumn (Bierzychudek 1982). The number of herb species which are able to grow under an oakhornbeam forest canopy is lower than the number of species in open areas (e.g., meadows, canopy gaps in deciduous forests, etc.). In general, forest associations have lower herb species diversity (31-56 species at $1600 \mathrm{~m}^{2}$; Decocq 2000) in comparison with meadows (77-89 plant species at $25 \mathrm{~m}^{2}$; Ś kornik et al. 2008) and open areas (50-90 species at $1000 \mathrm{~m}^{2}$; Weibull et al. 2003). Most of the herb layer species in an oakhornbeam forest are perennials, while annuals are rare. The dominance of perennial plant species in the flora of this forest association is caused, among other factors, by reduced life expectancy of seeds and much higher probability of seedling death (Bierzychudek 1982). Annuals appear mostly in gaps and forest borders. Aboveground shoots of forest perennials mostly live less than one year. In this way, they resemble annuals but in contrast they have belowground storage organs that store much more energy needed for growth and survival during early spring phenological stages of growth, than do seeds. Energy captured during photosynthesis and stored belowground is used for growth and development of plant organs and to survive periods of unfavorable environmental conditions. An individual can bloom when it has accumulated a sufficient pool of energy and resources (Dafni et al. 1981). On the other hand, summer-green herb species have smaller storage organs. These plants are characterized by low photosynthesis ratio, high carbon dioxide assimilation ratio, low light compensation point, durable, thin or low density leaves (to capture more photons), and low respiration ratio (Reich et al. 2003). Both groups (spring ephemerals and summer-green plants) are usually clonal plants. Clonality is an adaptation of plants to live in heterogenous environments with regard to water, nutrient, or light conditions (Antos and Zobel 1984). Clonal plants can share water, nutrients, and products of photosynthesis between ramets (individuals) and due to physiological integrity among ramets, can form a crop of individuals even when soil or light conditions are unfavorable (Chesson and Peterson 2002).

Net primary production of the herb layer is negatively correlated with canopy closure (Axmanová et al. 2011; Nabuurs 1996). Results obtained by Axmanová et al. (2011) do not indicate that herb layer net primary production is correlated with nutrient concentrations in soils in Central European oak forests. These results indicate that light is the most limiting resource in deciduous forests, while nutrient concentration is sufficient for growth and development of herbaceous plants. Competition between plants for environmental resources determines population traits like density, shoot mass, and biomass distribution. For example, a negative correlation between density and shoot mass of individuals was observed by Enquist et al. (1998). Increasing densities of plants cause increasing plant association biomass, but above a certain level association biomass starts decreasing (Chu et al. 2008; Stoll et al. 2002). However, in natural associations, these relationships are more complex because various species can use different environmental resources in a complementary fashion.

In clonal plants only a part of the shoots create flowers. In general, number of flowers are correlated to resource availability. Plants growing in favorable 
conditions create more flowers (Iason and Hester 1993). In the case of insect-pollinated species, the availability of pollinators may be a limiting factor (Brown and Mitchell 2001; Pleasants 1980; Sargent and Ackerly 2008; Waser 1978). That may suggest that number of flowering shoots may be an adaptation to the availability of pollinators, while large number of flowering shoots may be a waste of resources.

The aims of the study were to compare dynamics of shoot biomass, density, and share of flowering shoots of two spring ephemerals and two summer-greens which dominate the herb layer of oak-hornbeam deciduous forest over two consecutive growing seasons. We take into account growth ratio of each species, relationship between density and shoot biomass, and relationship between shoot biomass and share of flowering shoots. We hypothesized that shoots of spring ephemerals would have higher growth ratio than summer-greens due to shorter period needed for shoot development. Furthermore, we suppose that shoot biomass will be negatively correlated with shoot density, and shoot biomass will be positively correlated with the share of flowering shoots. Numerous publications consider relationships between biodiversity, plant density, vegetation cover, biomass, or shoot biomass (Chu et al. 2008; Loreau et al. 2001; Naeem et al. 1996; Stoll et al. 2002). Most of the cited studies are focused on Poaceae and annual plants, but seasonal patterns are neglected or rarely addressed. Thus, our study provides rare evidence from natural associations of clonal plants, while addressing an interesting question about how these relationships are shaped in clonal species. The novelty of this study is comparisons among biomass, density, and dynamics of the share of flowering shoots, of herbaceous clonal plants occurring in the natural association of oakhornbeam forest during two growing seasons.

\section{Material and methods}

The study was conducted in an oak-hornbeam forest association (Stellario holosteae-Carpinetum betuli). The research site (12 ha) was located in the Różańsko Forest District (NW Poland, 52 $52^{\prime} 30^{\prime} \mathrm{N}, 1^{\circ} 45^{\prime} 22^{\prime}$ $\mathrm{E})$. The research site is adjacent to the riparian forest on the northeast side and thus we excluded this part from the analysis. The research area was located on a slight slope with SW exposure. Stand species composition of well-preserved Stellario holosteaeCarpinetum betuli association (Rawlik et al. 2012) is composed mostly of beech Fagus sylvatica (70\%), hornbeam Carpinus betulus, oak Quercus robur, and sycamore Acer pseudoplatanus (Plan Urzadzenia Lasu 2006). Additional description of the study site is given by Rawlik et al. (2012). Mean annual temperature during 1971-2010 was $8.8^{\circ} \mathrm{C}$ and annual sum of precipitation was $541 \mathrm{~mm}$. During the field work (2010-2011) mean annual temperature was $8.8{ }^{\circ} \mathrm{C}$ and annual sum of precipitation was $615 \mathrm{~mm}$, based on data from Gorzów Wielkopolski meteorological station (Central Statistical Office 2011, 2012).

The dynamics of aboveground shoot biomass of the four most frequent plant species in the herb layer over the growing season is presented in this paper. Two of them are spring ephemerals (A. nemorosa, $F$. verna) and two are summer-green species ( $G$. luteum, G. odoratum). Plant density and biomass were determined from March 20 to October 30, 2010 (21 times) and March 19 to November 12, 2011 (24 times). During the spring 2010 and 2011, plants were harvested every 7 days, and during summer and autumn, every two weeks. In 2010, we collected plants from 7 to 9 randomly selected places (replications) and ten places in 2011. Plant material was collected from randomly located sample plots within the whole research site characterized by homogenous conditions, with respect to topography and vegetation. We excluded only places where plants were collected during a previous sampling. We included sample plots even when all of the studied species were not present. A single sample at each time consisted of a collection of plants from the area limited by a metal frame $(0.6 \times 0.6 \mathrm{~m})$. All living plants that grew within the frame were collected by cutting them at the soil surface. Number of shoots, separated by species and blooming or non-blooming status, was determined immediately after harvest. The collected plant material of each species studied was placed into separate envelopes with labels. In the case of Galeobdolon luteum, we did not distinguish blooming and nonblooming shoots due to low density of blooming shoots. Individuals rooted outside the frame, but having some parts inside the frame, were not taken into account. Individuals which were rooted inside the frame but had some parts outside the frame were wholly included in the data. 
The collected samples were dried at $65{ }^{\circ} \mathrm{C}$ to constant weight (at least 7 days) in forced-air dryers (ULE 600, Memmert GmbH + Co.KG, Germany), and then weighed with $0.0001 \mathrm{~g}$ accuracy (BP $210 \mathrm{~S}$, Sartorius, Göttingen, Germany; https://www.sartorius. dataweigh.com). In cases where samples were stored before biomass measurement in the laboratory, the plant material was dried again for one day. Thirty randomly selected shoots were chosen and biomass was measured from each sample plot. If within the sample plot less than 30 shoots of a particular herb species were collected, all shoots were weighed. Shoots were weighted separately to obtain individual biomass for each shoot. Thus, if we collected ten sample plots, the possible maximal number of weighed shoots was 300 , so we had 300 replications of individual shoot biomass for each time of collection for each species. In total, we measured 17,189 shoots. In the table and figure, we used median values due to skewness of results. We used Kruskal-Wallis tests $(\mathrm{p}<0.05)$ to obtain statistically significant differences between species. Shapiro-Wilk tests were done to estimate a distribution of the traits analyzed. Statistical analyses were carried out in Statistica 10.0 software.

Based on the data obtained, we calculated (a) maximal shoot biomass as mean of maximums from 2010 and 2011, and as maximal shoot biomass, we used the median value from the time when shoot median biomass was the highest; (b) maximal shoot density as mean of maximums from 2010 and 2011, and as maximal shoot density, we use the value from the time when shoot average density was the highest, based on 7-10 sample plots; (c) shoot life expectancy was the period in days during the growing season when aboveground shoots were observed and collected; (d) period of shoot biomass increment was the time in days from beginning of growing season to the term when shoot biomass obtained its peak; (e) growth ratio was the quotient of maximal shoot biomass by period of shoot biomass increment; (f) share of blooming shoots was the quotient of generative shoot density to total shoot density in the term of maximal shoot density (sum of vegetative and generative).

\section{Results}

Dynamics of biomass growth (increment) differed between spring ephemerals and summer-green herb species (Fig. 1). In fact, aboveground shoots of spring ephemerals were characterized by shorter life cycles than summer-green species; presence of summergreen species shoots were observed for almost all of the growing seasons. The highest growth ratio of vegetative shoots was observed for A. nemorosa $0.857 \mathrm{mg} \mathrm{day}^{-1}$, a lower value was observed for $G$. odoratum $-0.722 \mathrm{mg} \mathrm{day}^{-1}$, and growth ratios almost two-times lower were observed for $F$. verna $0.467 \mathrm{mg} \mathrm{day}^{-1}$ and G. luteum $-0.448 \mathrm{mg} \mathrm{day}^{-1}$. Thus, these results show no difference in growth ratio between the spring ephemerals and summer-green species. The spring ephemerals had lower maximal shoot biomass in comparison with summer-greens, which grew longer (Table 1).

For three of the species, biomass of blooming shoots was higher than vegetative shoots in all terms (Fig. 1). For example, maximal biomass (over growing season, based on median value) of A. nemorosa blooming shoots was twice as high as biomass of vegetative shoots. The highest differences were found for $F$. verna-maximal blooming shoot biomass was 4.4 times higher than biomass of vegetative shoots (Table 1). G. odoratum blooming shoots had almost $40 \%$ higher biomass than vegetative shoots (Table 1). Density of blooming shoots of G. luteum was very low within the study site and blooming shoots occurred very rarely within the sample plots.

Vegetative shoots of A. nemorosa were more numerous than blooming shoots. Consequently, blooming shoots had a low share of total population biomass. For instance maximal density of blooming shoots was 74 per $\mathrm{m}^{2}$. Maximal density of vegetative shoots was 1046 per $\mathrm{m}^{2}$. Density of blooming shoots was fourteen times lower than that of vegetative shoots. The highest average biomass of vegetative shoots was $42 \mathrm{mg}$, whereas the highest biomass of blooming shoots was $85.8 \mathrm{mg}$ (Table 1). Biomass of the vegetative shoots increased sharply between March to the beginning of May (Fig. 1). Daily growth ratio for vegetative shoots was $0.857 \mathrm{mg} \mathrm{day}^{-1}$. The blooming shoots grew rapidly from the beginning of the growing season to the end of April. Daily growth ratio was $1.907 \mathrm{mg} \mathrm{day}^{-1}$ per blooming shoot. After rapid growth ratio, shoots of $A$. nemorosa reached 


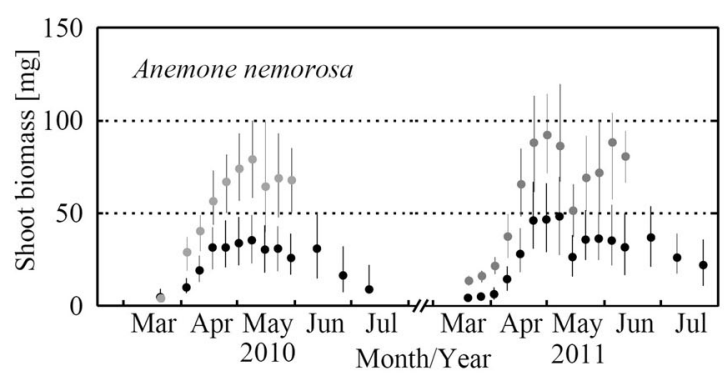

Median and interquartile range of:

- Vegetative shoots

$\phi$ Flowering shoots
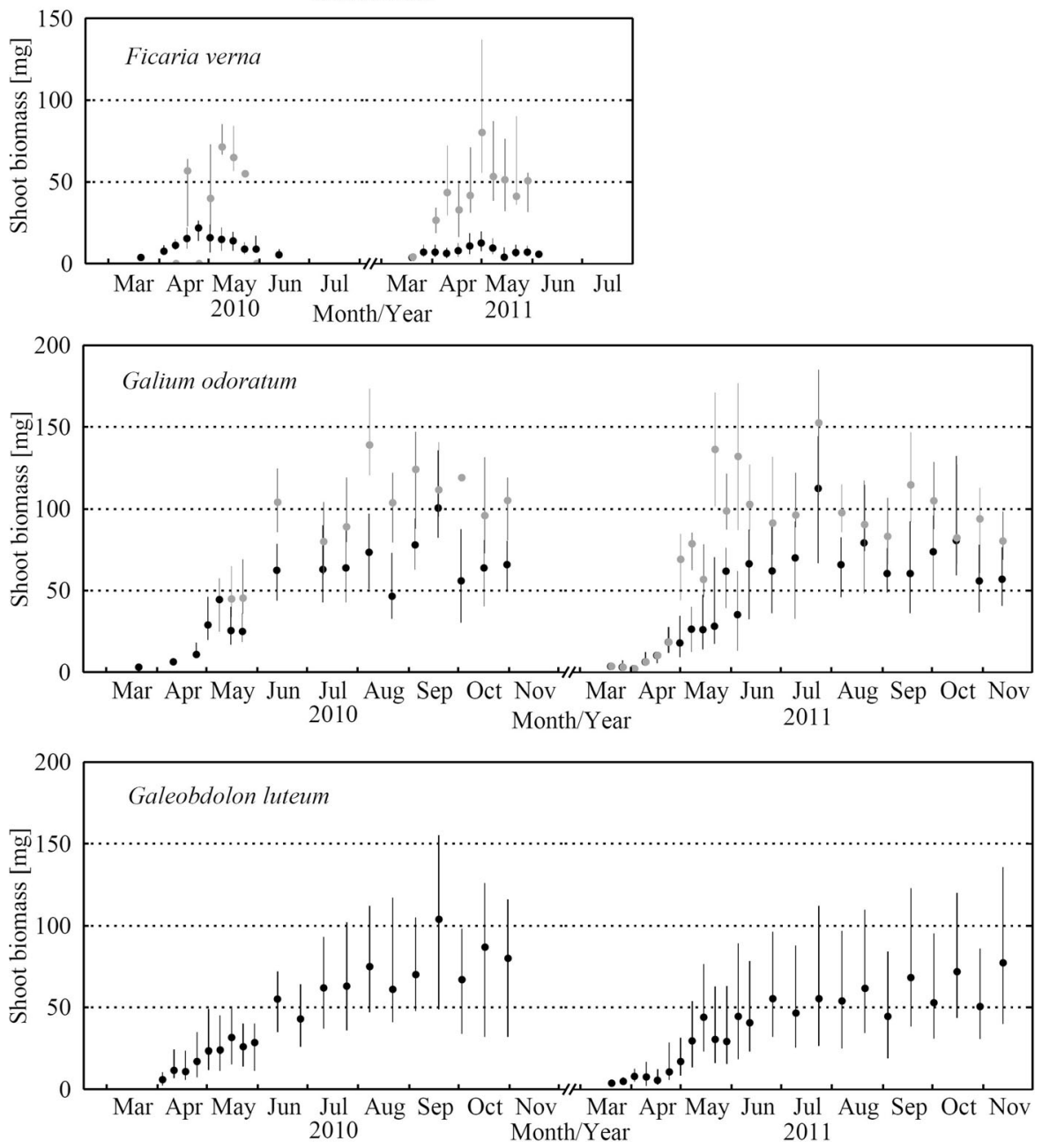

Fig. 1 Changes of median shoot biomass of four herb layer species: Anemone nemorosa, Ficaria verna, Galium odoratum, and Galeobdolon luteum over 2010 and 2011 growing seasons.

their highest individual biomass, and then the biomass decreased immediately to total disappearance of this species from the herb layer. In brief, A. nemorosa shoots grew for ca. 50 days, and after the next ca. 50 days their density diminished to less than $5 \%$ of the highest density observed during the growing season.
Medians based on values of shoot biomass of shoots collected from 7 to 10 sample plots. Points represent median values and the vertical lines show interquartile ranges

Aboveground shoots of $F$. verna were observed from March to the first half of June (80 days). Maximal density of vegetative shoots during the above-mentioned periods was $449.4 \mathrm{~m}^{-2}$. Maximal density of blooming shoots reached $10.1 \mathrm{~m}^{-2}$. The vegetative shoot biomass increased until the end of 
Table 1 Selected characteristics of analyzed plant populations

\begin{tabular}{|c|c|c|c|c|c|c|c|}
\hline & \multicolumn{2}{|c|}{ Anemone nemorosa } & \multicolumn{2}{|c|}{ Ficaria verna } & \multicolumn{2}{|c|}{ Galium odoratum } & \multirow{2}{*}{$\begin{array}{l}\text { Galeobdolon } \\
\text { luteum } \\
\text { Vegetative }\end{array}$} \\
\hline & Vegetative & Blooming & Vegetative & Blooming & Vegetative & Blooming & \\
\hline $\begin{array}{l}\text { Max shoot biomass (median value) } \\
{[\mathrm{mg}]^{\mathrm{a}}}\end{array}$ & $42.0 \mathrm{~b}$ & $85.8 \mathrm{c}$ & $17.4 \mathrm{a}$ & $75.9 \mathrm{~cd}$ & $106.5 \mathrm{~cd}$ & $145.8 \mathrm{~d}$ & $90.6 \mathrm{c}$ \\
\hline $\begin{array}{l}\text { Max shoot density } \\
{\left[\text { shoots } \mathrm{m}^{-2}\right]^{\mathrm{b}}}\end{array}$ & 1046.0 & 74.0 & 449.4 & 10.1 & 62.2 & 21.4 & 98.4 \\
\hline Shoot life expectancy [days $]^{c}$ & 119 & 77 & 80 & 49 & 231 & 182 & 224 \\
\hline 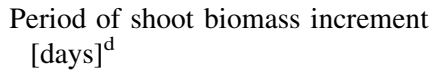 & 49 & 46 & 38 & 46 & 154 & 133 & 210 \\
\hline $\begin{array}{l}\text { Growth ratio } \\
{\left[\mathrm{mg} \mathrm{day}^{-1}\right]^{\mathrm{e}}}\end{array}$ & 0.857 & 1.907 & 0.467 & 1.686 & 0.722 & 1.102 & 0.448 \\
\hline Share of blooming shoots $[\%]^{\mathrm{f}}$ & 3.8 & & 1.9 & & 10.6 & & - \\
\hline
\end{tabular}

Values in the table are means from 2010 and 2011. In the case of Galeobdolon luteum only vegetative shoots are distinguished. Kruskal-Wallis tests $(\mathrm{p}<0.05)$ were performed for maximal shoot biomass

${ }^{a}$ Firstly we obtained maximal median in a given time (based on maximal 300 shoots collected on 7-10 sample plots) in years 2010 and 2011, then we calculated an average based on medians form 2010 and 2011

${ }^{b}$ Firstly we obtained averages of density in a given time (based on 7-10 sample plots), next we used maximal values form 2010 and 2011 to present mean values in the table

${ }^{c}$ Shoot life expectancy was the period in days during the growing season when aboveground shoots of species were observed and collected

${ }^{\mathrm{d}}$ Period of shoot biomass increment was the time in days from beginning of growing season to the term when shoot biomass obtained its peak

${ }^{\mathrm{e}}$ Growth ratio was the quotient of maximal shoot biomass by period of shoot biomass increment

${ }^{\text {f }}$ Share of blooming shoots was the quotient of generative shoot density to total shoot density in the terms of maximal shoot density (sum of vegetative and generative)

April, when it reached the highest values during the growing season $(17.4 \mathrm{mg})$. For blooming shoots the highest biomass was observed at the beginning of May (75.9 mg). Biomass of blooming shoots of $F$. verna was similar to A. nemorosa blooming shoots. Daily individual biomass growth ratio of $F$. verna vegetative shoots in March and April was $0.467 \mathrm{mg} \mathrm{day}^{-1}$. However, blooming shoots of $F$. verna grew $1.686 \mathrm{mg} \mathrm{day}^{-1}$ (Table 1).

Galium odoratum shoots were observed during entire growing seasons. Biomass of vegetative shoots (Fig. 1) increased continuously, but the date with highest shoot biomass could not be determined. The highest vegetative shoot biomass was observed in the August-September period. Maximal average density was 62.2 per $\mathrm{m}^{2}$ for vegetative shoots and 21.4 per $\mathrm{m}^{2}$ for blooming shoots. The highest biomass was 106.5 for vegetative shoots and $145.8 \mathrm{mg}$ for blooming shoots. Taking into account values observed in individual sample plots, it was found that the highest density was 328 vegetative shoots per $\mathrm{m}^{2}$ and 139 blooming shoots per $\mathrm{m}^{2}$ (the highest values from two growing seasons).

Aboveground shoots of Galeobdolon luteum were present in the herb layer for entire growing seasons. Biomass dynamic of aboveground shoots (Fig. 1) shows continuous growth during both growing seasons. The highest biomass value of current year shoots was observed during September-November, thus shoots developed for 168 days in 2010 and 238 days in 2011 (Fig. 1). The maximal shoot biomass increased to $90.6 \mathrm{mg}$. Maximal density of G. luteum shoots was 98.4 shoots per $\mathrm{m}^{2}$.

We did not find any relationship between density of blooming shoots and biomass of vegetative shoots for any herb species studied. Also, we did not find any 
relationship between density of vegetative shoots and shoot biomass. However, density of blooming shoots was positively correlated with density of vegetative shoots for all species analyzed. Individual biomass of blooming shoots was positively correlated with the individual biomass of vegetative shoots.

\section{Discussion}

In nutrient-rich deciduous forests light is the factor limiting biomass production of the herbaceous layer (Axmanová et al. 2011; Elemans 2003). Plant species occurring in these environments represent two general adaptations: spring ephemerals in which aboveground organs grow for a short period of the year when they can use light before canopy closure, and summergreens which grow throughout the whole growing season and are adapted to limited light under the tree canopy. Aboveground organs of spring ephemerals Anemone nemorosa and Ficaria verna grow up through the end of June, and after that plants fall into dormancy as storage organs. For example, in eastern North American maple-beech forest the spring ephemeral Erythronium americanum occurs up to the beginning of June (Tremblay and Larocque 2001), similarly, in oak-beech-hornbeam forest in the Netherlands, the spring ephemeral Allium ursinum reaches peak biomass during a two-week period of May (Werger and Laar 1985). The biomass peak in the herb layer of non-degraded floodplain forest was observed at the end of May, and spring ephemerals were largely responsible for that (Czapiewska et al. 2019).

We hypothesized that the spring ephemerals Anemone nemorosa and Ficaria verna will have greater growth ratios than the summer-greens Galeobdolon luteum and Galium odoratum. In fact, the greatest growth ratio was observed for Anemone nemorosa, but growth ratio for Ficaria verna was lower than the growth ratio for Galium odoratum and quite similar to Galeobdolon luteum. Both spring ephemerals reached lower shoot biomass than summer-greens. That suggests that low shoot biomass, rather than high growth ratio, is an adaptation to short growth period. However, due to high densities of spring ephemerals, they are responsible for the whole herb layer biomass peak, and they had a dominant share of herb layer biomass (Rawlik et al. 2012).
Literature data confirm that a negative relationship exists between plant density and individual biomass (Damgaard et al. 2002; Franco and Kelly 1998; White and Harper 1970). Not all authors have concurred that the correlation is described by a $-3 / 2$ regression coefficient in logarithmic scales (Weller 1987). Our results do not confirm existence of this relationship. In cases of the analyzed species, we do not recognize a correlation between density and individual shoot biomass. We suggest that this observation is caused by natural conditions under which research occurs. Natural populations aim to achieve optimal density and biomass rather than extreme values of density or biomass. In natural populations effects of other species are also significant, but they are neglected in experimental data sets.

Specimens with high biomass have greater seed production because it is bound to energetic effort. When fertility of a population is limited, genetic variance inside the population is also limited (Weiner and Thomas 1986). We have studied populations in which the shares of blooming shoots were relatively small. Generative shoots had higher biomass for all analyzed species. For example, the most visible differences occurred in spring ephemerals, whereas the least differences occurred in the G. odoratum population. Moreover, the share of blooming shoots was much higher in $G$. odoratum than spring ephemerals. Size hierarchy, which determines blooming of the largest specimens, is observed in many plant populations (Weiner 1985).

Biomass designation for blooming is a high-risk investment. Plants designate more resources for blooming in optimal site conditions and sufficient nutrient concentrations than in poor habitats. Production of flowers and seeds require limiting nutrients and products: nitrogen, phosphorus, and lipids (Bloom et al. 1985). We expected to obtain a positive correlation between shoot biomass and number of flowering shoots per area. High average shoot biomass indicates favorable site conditions and sufficient amounts of nutrients and light (Müller et al. 2000; Vermeer and Berendse 1983), and thus should translate to numerous flowering shoots (Iason and Hester 1993) but we did not observe those correlations in our study. In three of the species (A. nemorosa, F. verna, and $G$. odoratum), the number of flowering shoots were a specific portion of all shoots and the number of flowers showed no dependence on shoot biomass 
indicating site richness. These observations suggest that number of flowering shoots in genets is evolutionarily determined and benefits from favorable site conditions are used in other ways. A possible explanation is sharing the resources among shoots due to physiological integration of ramets (Antos 1988; Chesson and Peterson 2002).

We observed right skewness in shoot biomass distribution. Thus, we observed low numbers of shoots with high biomass and numerous shoots with low biomass. Asymmetric, right skewness in distribution of shoot biomass might be considered as an effect of competition for light. Competition for soil resources causes a symmetric distribution of shoot biomass (Schwinning and Weiner 1998). Competition for light is precisely described by a competition model based on a relationship between plant size and resource use. Larger specimens shade smaller ones, and larger specimens also absorb more light and grow faster, increasing the size difference. Large shoots limit growth of small shoots but small shoots do not limit growth of large ones, hence that type of competition is called one-sided competition (Weiner and Thomas 1986). Skewness of biomass distribution is clearer in crowded populations (Weiner 1985; Weiner and Damgaard 2006).

All of the species studied are insect pollinated (Klotz et al. 2002). Pollination by insects is bound to many plant population traits. Plant density should be high so that insects can transfer pollen among flowers. In cases of non-clonal plants it was demonstrated that high densities are related to high numbers of cross pollination. A similar relationship was also found for genets of clonal plants (Charpentier 2002; Sõber et al. 2009). In the clonal plant species studied here, genetic variability of whole genets is transferred to the next generation by blooming shoots. Additionally, blooming shoots may be genetically identical to many vegetative shoots (Eriksson 1993; Stehlik and Holderegger 2000). Clonal plants are adapted to existence in small populations, which are usually not attractive for pollinators, and large numbers of flowers cause higher attractiveness for pollinators. That phenomenon is not beneficial when a population has a few genets (Whigham 2004). Many papers indicate existence of competition among plants for pollinators (Brown and Mitchell 2001; Pleasants 1980; Sargent and Ackerly 2008; Waser 1978). It is possible that high density of blooming plants is not beneficial, due to the limited number of pollinators. The best pollination effectiveness requires strictly determined density of flowers (Stout et al. 1998). Production of large numbers of flowers without guarantee of pollination is a waste of resources. It seems that right skewness of shoot biomass distribution and low number of blooming shoots is unfavorable for the population. On one hand, number of blooming shoots is limited by resources, but on the other hand the number of flowers may be an adaptation for availability of pollinators. Therefore, the share of blooming shoots is balanced by site resource availability and pollination effectiveness.

In the case of vegetative shoots, we did not observe higher growth ratio in spring ephemerals than in summer-greens. The highest growth ratio was observed for spring ephemeral Anemone nemorosa$0.9 \mathrm{mg} \mathrm{day}^{-1}$, lower ratios were observed for summer-green Galium odoratum $-0.7 \mathrm{mg} \mathrm{day}^{-1}$ and for spring ephemeral Ficaria verna-0.5 $\mathrm{mg} \mathrm{day}^{-1}$. The lowest growth ratio was observed for summer-green Galeobdolon luteum- $0.4 \mathrm{mg} \mathrm{day}^{-1}$. In the case of blooming shoots, spring ephemerals Anemone nemorosa and Ficaria verna had higher growth ratios (1.9 and $1.7 \mathrm{mg} \mathrm{day}^{-1}$, respectively) than summer-green Galium odoratum $\left(1.1 \mathrm{mg}\right.$ day $\left.^{-1}\right)$. This shows that summer-greens can grow as fast as spring ephemerals even under unfavorable light conditions during tree canopy closure. Due to longer period of growth the summer-greens reach larger shoot biomass than the spring ephemerals. Thus, small shoot biomass characterizes spring ephemerals rather than high growth ratio. Spring ephemerals reach high densities, which translate to dominance in total biomass of the herb layer. Although summer-greens reach higher shoot biomass than spring ephemerals, they reach lower densities, and thus the peak of biomass is lower than for spring ephemerals. The share of blooming shoots was low in spring ephemerals, nearly $4 \%$ for Anemone nemorosa and $2 \%$ for Ficaria verna, while densities reached 74 per $\mathrm{m}^{2}$ for Anemone nemorosa and 10 per $\mathrm{m}^{2}$ for Ficaria verna. For Galium odoratum, the share of blooming shoots was over $10 \%$ and density reached 21 blooming shoots per $\mathrm{m}^{2}$. In the case of Galium odoratum, high share of blooming shoots may be caused by low density of all shoots, yielding the number of flowers is necessary to attract pollinators. On the other hand, spring ephemerals had low shares of blooming shoots with densities similar to summer- 
greens. This suggests that the number of blooming shoots is an adaptation to availability of pollinators.

Acknowledgements The study was financially supported by the Institute of Dendrology, Polish Academy of Sciences, Kórnik, Poland. We would like to thank Dr. Lee E. Frelich (The University of Minnesota Center for Forest Ecology, USA) for linguistic revision of the manuscript. We thank reviewers for valuable comments and suggestions which improved our manuscript.

\section{Compliance with ethical standards}

Conflict of interest The authors declare that they have no conflict of interest.

Open Access This article is licensed under a Creative Commons Attribution 4.0 International License, which permits use, sharing, adaptation, distribution and reproduction in any medium or format, as long as you give appropriate credit to the original author(s) and the source, provide a link to the Creative Commons licence, and indicate if changes were made. The images or other third party material in this article are included in the article's Creative Commons licence, unless indicated otherwise in a credit line to the material. If material is not included in the article's Creative Commons licence and your intended use is not permitted by statutory regulation or exceeds the permitted use, you will need to obtain permission directly from the copyright holder. To view a copy of this licence, visit http://creativecommons.org/licenses/by/4.0/.

\section{References}

Abraitiené J, Marozas V (2011) Phenology of herbaceous vegetation in broadleaved forest of Kamsa botanical-zoological reserve. Acta Biol Univ Daugavipliensis 1(2):226-230

Antos JA (1988) Underground morphology and habitat relationships of three pairs of forest herbs. Am J Bot 75:106-113. https://doi.org/10.1002/j.1537-2197.1988. tb12164.x

Antos JA, Zobel DB (1984) Ecological implications of belowground morphology of nine coniferous forest herbs. Bot Gaz 145:508-517. https://doi.org/10.1086/337486

Axmanová I, Zelený D, Li Ch, Chytrý M (2011) Environmental factors influencing herb layer productivity in Central European oak forests: insights from soil and biomass analyses and a phytometer experiment. Plant Soil 342:183-194

Bierzychudek P (1982) Life histories and demography of shadetolerant temperate forest herbs: a review. New Phytol 90:757-776

Bloom AJ, Chapin FS, Mooney HA (1985) Resource limitation in plants-an economic analogy. Annu Rev Ecol Syst 16:363-392

Brown BJ, Mitchell RJ (2001) Competition for pollination: effects of pollen of an invasive plant on seed set of a native congener. Oecologia 129:43-49
Central Statistical Office (2011) Statistical Yearbook of the Republic of Poland. Statistical Publishing Establishment, Warszawa. https://stat.gov.pl/cps/rde/xbcr/gus/ rs_rocznik_statystyczny_rp_2011.pdf. Accessed 17 Jan 2020.

Central Statistical Office (2012) Statistical Yearbook of the Republic of Poland. Statistical Publishing Establishment, Warszawa. https://stat.gov.pl/cps/rde/xbcr/gus/RS rocznik_statystyczny_rp_2012.pdf. Accessed 17 Jan 2020.

Chapin FS, Schulze E, Mooney HA (1990) The ecology and economics of storage in plants. Annu Rev Ecol Syst 21:423-447

Charpentier A (2002) Consequences of clonal growth for plant mating. Evol Ecol 15:521-530

Chesson P, Peterson AG (2002) The quantitative assessment of the benefits of physiological integration in clonal plants. Evol Ecol Res 4:1153-1176

Chu C-J, Maestre FT, Xiao S, Weiner J, Wang Y-S, Duan Z-H, Wang G (2008) Balance between facilitation and resource competition determines biomass-density relationships in plant populations. Ecol Lett 11:1189-1197

Czapiewska N, Dyderski MK, Jagodziński AM (2019) Seasonal dynamics of floodplain forest understory-impacts of degradation, light availability and temperature on biomass and species composition. Forests 10:22

Dafni A, Cohen D, Noy-Mier I (1981) Life-cycle variation in geophytes. Ann Mo Bot Gard 68(4):652-660

Damgaard C, Weiner J, Nagashima H (2002) Modelling individual growth and competition in plant populations: growth curves of Chenopodium album at two densities. J Ecol 90:666-671

Decocq G (2000) The 'masking effect' of silviculture on substrate-induced plant diversity in oak-hornbeam forests from northern France. Biodivers Conserv 9:1467-1491

Elemans M (2003) Light, nutrients and the growth of herbaceous forest species. Acta Oecologica 26:197-202

Eliáš P (1984) Adaptations of understorey species to exist in temperate deciduous forests. Tasks for Vegetation Science 13:157-165

Enquist BJ, Brown JH, West GB (1998) Allometric scaling of plant energetics and population density. Nature 395:163-165

Eriksson O (1993) Dynamics of genets in clonal plants. Trends Ecol Evol 8(9):313-316

Franco M, Kelly CK (1998) The interspecific mass-density relationship and plant geometry. Proc Natl Acad Sci USA 95:7830-7835

Iason GR, Hester AJ (1993) The response of heather (Calluna vulgaris) to shade and nutrients-predictions of the carbonnutrient balance hypothesis. J Ecol 81(1):75-80

Jagodziński AM, Dyderski MK, Rawlik K, Kątna B (2016) Seasonal variability of biomass, total leaf area and specific leaf area of forest understory herbs reflects their life strategies. For Ecol Manag 374:71-81

Klotz S, Kühn I, Durka W (2002) BIOLFLOR-Eine Datenbankzubiologischökologischen Merkmalen der Gefäßpflanzen in Deutschland. Bundesamt für Naturschutz Schriftenreihefür Vegetationskunde, Bonn

Krotoska T (1961) Obserwacje fenologiczne w QuercetoCarpinetum medioeuropaeum Tx. 1936 i w Querceto-Potentilletum albae Libbert 1933 w Wielkopolskim Parku 
Narodowym. Prace Monogr nad Przyrodą Wielkop Parku Narodowego pod Poznaniem 3(6):1-159

Lapointe L (2001) How phenology influences physiology in deciduous forest spring ephemerals. Physiol Plant 113:151-157

Loreau M, Naeem S, Inchausti P, Bengtsson J, Grime JP, Hector A, Hooper DU, Huston MA, Raffaelli D, Schmid B, Tilman D, Wardle DA (2001) Biodiversity and ecosystem functioning: current knowledge and future challenges. Science 294:804-808. https://doi.org/10.1126/science.1064088

Morin PJ (2009) Chapter 11: Succession. In: Morin P.J. Community Ecology. pp. 339-365. Blackwell Sciences, Oxford.

Müller I, Schmid B, Weiner J (2000) The effect of nutrient availability on biomass allocation patterns in 27 species of herbaceous plants. Perspect Plant Ecol Evol Syst 3:115-127. https://doi.org/10.1078/1433-8319-00007

Nabuurs GJ (1996) Quantification of herb layer dynamics under tree canopy. For Ecol Manage 88:143-148

Naeem S, Håkansson K, Lawton JH, Crawley MJ, Thompson LJ (1996) Biodiversity and plant productivity in a model assemblage of plant species. Oikos 76:259-264

Plan Urządzenia Lasu dla Nadleśnictwa Różańsko wg stanu na dzień 01.01.2006 na okres 2006-2015 (2006) Przedsiębiorstwo Wielobranżowe Krameko. Maszynopis w Nadleśnictwie Różańsko.

Pleasants JM (1980) Competition for bumblebee pollinators in rocky mountain plant communities. Ecology 61(6):1446-1459

Rawlik M, Jagodziński AM, Janyszek S (2012) Seasonal changes in the understorey biomass of an oak-hornbeam forest Stellario holosteae-Carpinetum betuli. Forest Research Papers 73(3):221-235

Reich PB, Wright IJ, Cavender-Bares J, Craine JM, Oleksyn J, Westoby M, Walters MB (2003) The evolution of plant functional variation: traits, spectra, and strategies. Int J Plant Sci 164:143-164

Sargent RD, Ackerly DD (2008) Plant-pollinator interactions and the assembly of plant communities. Trends Ecol Evol 23(3):123-130

Schwinning S, Weiner J (1998) Mechanisms determining the degree of size asymmetry in competition among plants. Oecologia 113:447-455

Škornik S, Šajna N, Kramberger B, Kaligarič S, Kaligarič M (2008) Last remnants of riparian wooded meadows along the middle Drava River (Slovenia): species composition is a response to light conditions and management. Folia Geobotanica 43:431-445
Sõber V, Teder T, Moora M (2009) Contrasting effects of plant population size on florivory and pollination. Basic Appl Ecol 10:737-744

Stehlik I, Holderegger R (2000) Spatial genetic structure and clonal diversity of Anemone nemorosa in late successional deciduous woodlands of Central Europe. $\mathrm{J}$ Ecol 88:424-435

Stoll P, Weiner J, Muller-Landau H, Müller E, Hara T (2002) Size symmetry of competition alters biomass-density relationships. Proc Soc Biol Sci 269:2191-2195

Stout JC, Allen JA, Goulson D (1998) The influence of relative plant density and floral morphological complexity on the behavior of bumblebees. Oecologia 117:543-550

Suzuki J, Stuefer J (1999) On the ecological and evolutionary significance of storage in clonal plants. Plant Species Biol 14:11-17

Tremblay NO, Larocque GR (2001) Seasonal dynamics of understory vegetation in four eastern Canadian forest types. Int J Plant Sci 162(2):271-286

Vermeer JG, Berendse F (1983) The relationship between nutrient availability, shoot biomass and species richness in grassland and wetland communities. Vegetatio 53:121-126. https://doi.org/10.1007/BF00043032

Waser NM (1978) Interspecific pollen transfer and competition between co-occurring plant species. Oecologia 36:223-236

Weibull A, Östman Ö, Granqvist $\AA$ (2003) Species richness in agroecosystems: the effect of landscape, habitat and farm management. Biodivers Conserv 12:1335-1355

Weiner J (1985) Size hierarchies in experimental populations of annual plants. Ecology 66(3):743-752

Weiner J, Damgaard C (2006) Size-asymmetric competition and size-asymmetric growth in a spatially explicit zone-of-influence model of plant competition. Ecol Res 21:707-712

Weiner J, Thomas SC (1986) Size variability and competition in plant monocultures. Oikos 47:211-222

Weller DE (1987) A reevaluation of the $-3 / 2$ power rule of plant self-thinning. Ecol Monogr 57(1):23-43

Werger MJA, van Laar EMJM (1985) Seasonal changes in the structure of the herb layer of a deciduous woodland. Flora 176:351-364

Whigham DF (2004) Ecology of woodland herbs in temperate deciduous forests. Annu Rev Ecol Evol Syst 35:583-621

White J, Harper JL (1970) Correlated changes in plant size and number in plant populations. J Ecol 58(2):467-485

Publisher's Note Springer Nature remains neutral with regard to jurisdictional claims in published maps and institutional affiliations. 